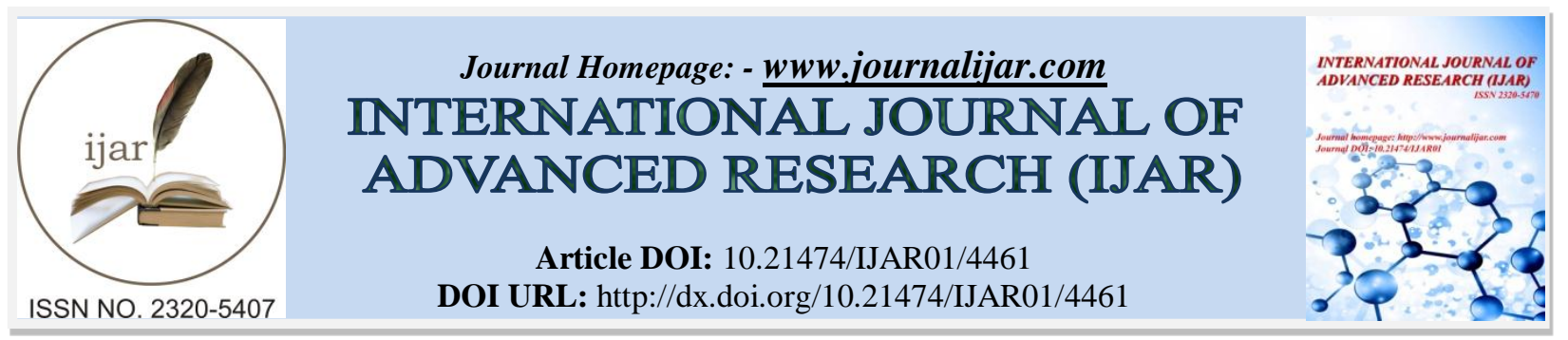

RESEARCH ARTICLE

\title{
OPTIMAL OPERATION OF A DISTRIBUTION SYSTEM SUPPLYING A BUILDING WITH RENEWABLE ENERGY RESOURCES.
}

Sunita Kumari and Sudhir Y Kumar.

Electrical Engineering Dept, CET, Mody University, Lakshmangarh, India.

\section{Manuscript Info}

Manuscript History

Received: 12 April 2017

Final Accepted: 14 May 2017

Published: June 2017

Key words:-

HOMER, DERs, Micro-grid, PV,

Optimization.

\section{Abstract}

For domestic consumers in rural areas, the source of electrical supply is diesel generators which emit carbon dioxide resulting in environmental pollution and it is costly too. Therefore, in present scenario, the need of an hour is to improve and provide efficient energy supply for rural areas. Hybrid Smart grid is a power system with distributed resources serving the whole community as an independent electrical island with the bulk power system. The aim of this paper is to simulate and do the mathematical modeling of each component and optimizing using HOMER (Hybrid Optimization Model for Electrical Renewable) Software in order to determine the economic feasibility of hybrid grid to ensure reliable power supply to load demand and minimization of cost.

In this paper, in first case photovoltaic system, wind turbine, converter are taken with storage battery \& diesel generator for backup and have been simulated and optimized for library in College of Engineering and Technology, MUST at, Lakshmangarh, Rajasthan 332311 , India. In second case, the system includes solar panel, battery, generator, converter and loads. In this study we calculate overall load in library. After knowing overall loads result for this library we simulate this data through HOMER tool and we compare the results of first and second case which is presented in this paper. The goal is to maximize energy output with least cost of energy from distributed energy resources (DERs) by optimization using HOMER. Performance of each component of model will be evaluated and sensitivity analysis will be performed to optimize the system at different conditions.

Copy Right, IJAR, 2017,. All rights reserved.

\section{Introduction:-}

In present scenario, the need of the hour is to better power system reliability and clean power in which Micro-grid is the primary concept. Also Experts have warned that fossil fuel are becoming more expensive and eventually will run out. Fossil and nuclear fuel resources are limited, requiring search for alternate sources of energy. Solar and Wind energy can play a vital role as renewable resources in India. For the off grid system, single technologies like solar photo voltaic and wind turbines cannot be considered efficient and reliable due to their variable nature in Climate. Use of single technology also causes over sizing of system. Seasonal variations of wind speed and solar radiation resources are complimentary to each other. Hybrid system is the combination of renewable energy resources along with non-renewable energy resources. Therefore, Hybrid system is more reliable and effective but hybrid system 
increases complexity in system. Optimization of hybrid system is required. India is densely populated country in all around the world and hence its energy demand is also more and increasing with time. Therefore it is necessary to interconnect other renewable energy resources for continuous power supply. In this paper, a hybrid system consist of PV Panel, wind turbine, Converter, Battery and Diesel Generator is designed for Library in College of Engineering and technology of Mody University of Science and Technology at Lakshmangarh in India. Two Simulations have been studied in this study with the HOMER Software, first arrangement consists of wind turbine, PV, DG and second arrangement consists of PV and DG. It also compares the cost of electricity from Utility Supply with these two Simulation results. HOMER Pro Micro grid Analysis Tool 3.8.6 (Evaluation Edition) is used for optimization of system.

\section{Homer Software:-}

HOMER software has been developed by National Renewable Energy Laboratory, USA in 1993[7]. It is used to evaluate the performance of the grid connected system as well as off grid system. HOMER performes three tasks, firstly simulation than optimization and at the last sensitive analysis. In simulation process, HOMER simulates the hybrid system for each hour for the year and determines its technical feasibility and its life cycle cost. In optimization process, HOMER simulates many combinations to find the best combination that fulfill the criteria of technical feasibility along with minimum life cycle cost. In sensitive analysis process HOMER performs many optimizations with some input assumptions to determine the effect of uncertainty and variation in model input [8].

\section{Site Location and Load Profile:-}

The proposed system designed used to power the Library of CET of MUST at Laxamangarh. The University is situated at latitude of $27^{\prime} 48.1$ " north and longitude of $75^{\prime} 2.2$ " east. In this study, the Library electrical load requirement is carefully estimated considering existing load profile. The demand has been estimated separately for all the months for one year considering the appliance holding and use patterns for library. Table 1 shows the total appliances used in library. In this study we consider the following profile of load:

- Four tube light glow throughout the night period in whole year.

- Fans are used during the entire summer session and few other months too.

- Library working time is 8:30 AM to $8 \mathrm{PM}$ in both the semesters.

- Library working time is 9 AM to 6 PM in both the semesters on Weekend.

- First semester is run from January to May and second semester is run from July to December.

Table 1:- Various Load Appliances

\begin{tabular}{|c|c|c|c|}
\hline Name of Device & Number of Device & Energy Consumption in (W) & $\begin{array}{c}\text { Total Energy Consumption in } \\
\text { Watt }\end{array}$ \\
\hline Fan & 58 & 60 & 3480 \\
\hline Tube Light & 78 & $\left(36^{*} 3=108\right)$ & 8424 \\
\hline Computer & 10 & 150 & 1500 \\
\hline Fax Machine & 1 & 1500 & 1500 \\
\hline Printer & 2 & 100 & 200 \\
\hline
\end{tabular}

Figure 1 shows the load profile for the library. It is found that average energy required is 117.09 KWh per day. Peak load is $18.57 \mathrm{KW}$ during the August month. Minimum load is in June and December period.

Figure 1:- Load Profile per day of the mentioned Site




\section{System Model and Components:-}

Sizing and optimization of hybrid model is done by hybrid optimization model for electric renewable software ( HOMER ).[2]

Case Study a) The proposed model contains solar photovoltaic modules, wind energy, generator with battery storage system for storage of excess generated electricity. Converter system isconnected between AC and DC link .$[6]$

Case Study b) The proposed model contains solar photovoltaic modules, generator with battery storage system for storage of excess generated electricity. Converter system is connected between AC and DC link .[6] The proposed system is shown in Figure 3. The HOMER software determines the optimal cost and sensitivity analysis of the given systems.

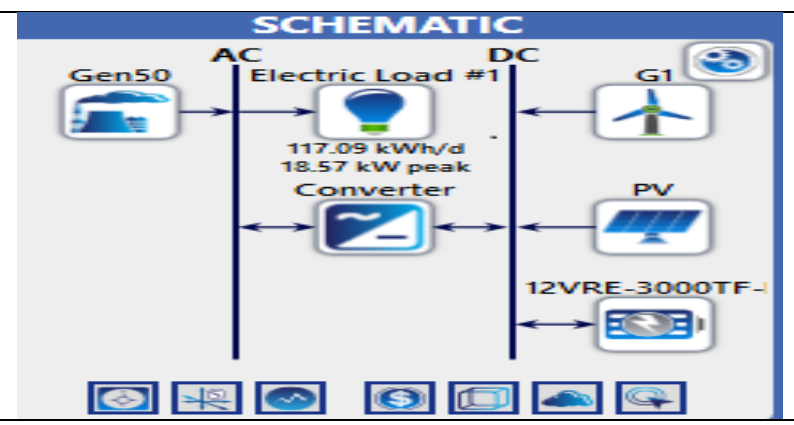

Figure 3:- DERs model in HOMER for cost optimization

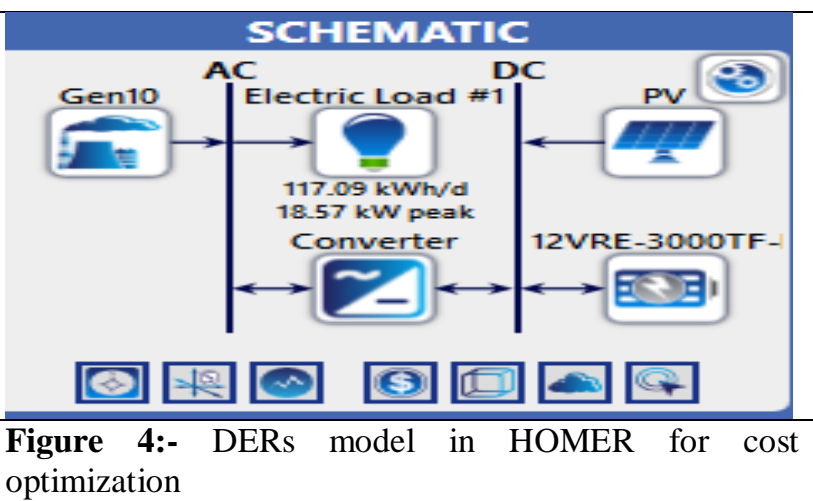

Table 2:- System Component Considered in this Study (1 US Dollar = 64.04 Indian Rs)

\begin{tabular}{|c|c|c|c|c|c|c|}
\hline Component & $\begin{array}{c}\text { Size } \\
(\mathbf{k W})\end{array}$ & $\begin{array}{c}\text { Capital } \\
\text { Cost } \mathbf{( \$ )}\end{array}$ & $\begin{array}{c}\text { Replacement } \\
\text { Cost } \mathbf{( \$ )}\end{array}$ & $\begin{array}{c}\text { O\&M Cost } \\
\mathbf{( \$ / y e a r )}\end{array}$ & Life Time & References \\
\hline a) PV Panel & 0.1 & 98 & 74 & 1 & 25 years & {$[\mathbf{1 0}]$} \\
\hline & 0.15 & 138 & 110 & 1 & 25 years & {$[\mathbf{1 0}]$} \\
\hline & 0.25 & 238 & 190 & 1 & 25 years & {$[10]$} \\
\hline b) PV Panel & 100 & $98,000.00$ & $74,000.00$ & 1000.00 & 25 years & {$[\mathbf{1 0}]$} \\
\hline Wind Turbine & 1 & 2307 & 1845 & 10 & 20 years & {$[12]$} \\
\hline a) Diesel Generator & 4 & 2739 & 2215 & 0.1 & $15000 \mathrm{hrs}$ & {$[14]$} \\
\hline b) Diesel Generator & 10 & 5000 & 5000 & $0.3($ per hr) & $15000 \mathrm{hrs}$ & {$[14]$} \\
\hline Battery & & 80 & 56 & 1 & $719 \mathrm{kWh}$ & \\
\hline Convertor & 1.5 & 542 & 433 & 5 & 15 years & {$[10]$} \\
\hline & 3 & 664 & 531 & 10 & 15 years & {$[10]$} \\
\hline & 7.5 & 1003 & 802 & 20 & 15 years & {$[10]$} \\
\hline
\end{tabular}

\section{Installation of Solar Photovoltaic Module:-}

After surveying different products focusing on the cost provided the following panel was chosen. The amount of global solar radiation that strikes earth's surface is indicated by solar resource. Solar radiation for this study area was obtained from National renewable lab energy database and National solar radiation database. An average solar radiation of $5.04 \mathrm{kWh} / \mathrm{m} 2 /$ day and a clearness index of 0.6 were identified for the study area. The solar PV array modeled in HOMER gives DC output directly proportional to incident solar radiation. Operation and maintenance $(\mathrm{O} \& \mathrm{M})$ cost is practically zero and its lifetime is 25 years. The following parameters have been considered like; the de-rating factor was taken as $85 \%$, ground reflectance was also considered as $20 \%$, slope 26.98 (latitude of the location) and azimuth 0 (south orientation). PV Panels are studied at $0,2,2.5,3,3.5,4,4.5,5,5.5,6,6.5,7,7.5,8$, $8.5,9$ and $9.5 \mathrm{~kW}$. 


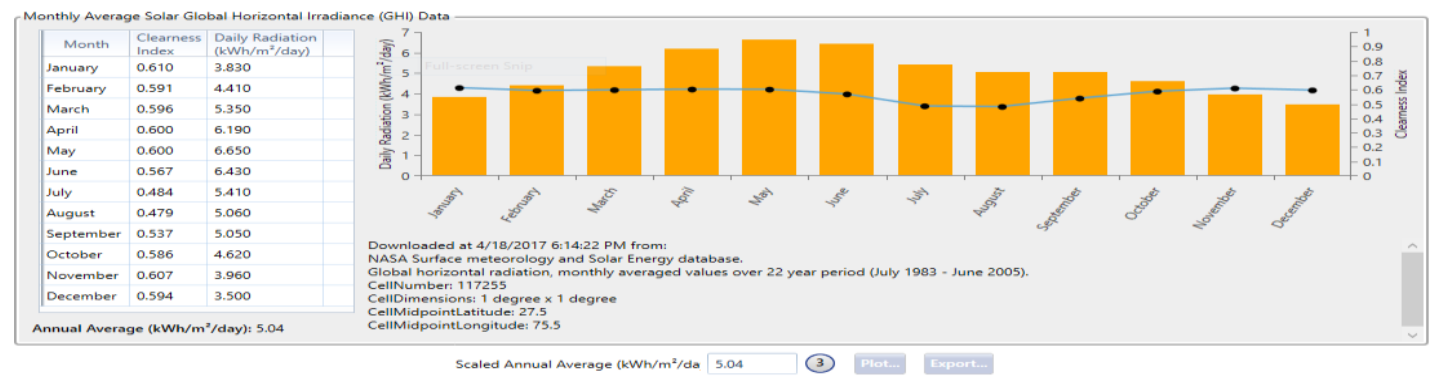

Figure 5:-

Installation of Diesel Generator:-

Global Horizontal radiation of study area

Diesel Generator for proposed model for 2 simulations is of rated capacity of $4 \mathrm{KW}$ and $10 \mathrm{KW}$ respectively. Generator delivers AC. The operation and maintenance cost of the generator is $\$ 0.030 / \mathrm{hr}$. Diesel can be transported between nearest pump to site. There for the transportation cost of the diesel is approximately $\$ 0.5 /$ liter. Diesel generators do not allow running at less than the minimum load ratio of 30\%. Lifetime operation of generation is about $15000 \mathrm{hr} .0,4,8$ and $12 \mathrm{~kW}$ Diesel Generators are studied. When hybrid energy system generate sufficient amount of power diesel generators work as a backup for the site. [8]

\section{Installation of Battery:-}

DC battery is used to store the energy and retain the energy when peak load appears by HOMER. Assumption is made that battery properties remain constant throughout its lifetime and are not affected by external factors. The nominal capacity of the selected battery is $2.94 \mathrm{kWh}$ with nominal voltage of $12 \mathrm{~V}$ for single battery and the amount of energy stored in a single battery is $2.94 \mathrm{kWh}$, maximum charge current is $57 \mathrm{~A}$, round-trip battery efficiency is taken as $85 \%$. Replacement cost for battery is assumed about $70 \%$ of its capital cost. Battery is studied at quantities of $0,10,20,50,100$ and 150 .

\section{Installation of Wind Turbine:-}

The wind turbine taken for this project work is $1 \mathrm{~kW}$ power rating. In this project installed cost was taken about $\$ 2307 / \mathrm{kW}$ [11]. Replacement cost of the wind turbine considered in this case is about $80 \%$ of capital cost after 20 year service life. Hub height is considered $25 \mathrm{~m} .0,1,2,3$ and 4 wind turbines are studied for simulation. The annual average wind speed for the location is $3.27 \mathrm{~m} / \mathrm{sec}$ with the anemometer height at 50 meters. Figure 5 presents graph of the average wind speed at our study site.

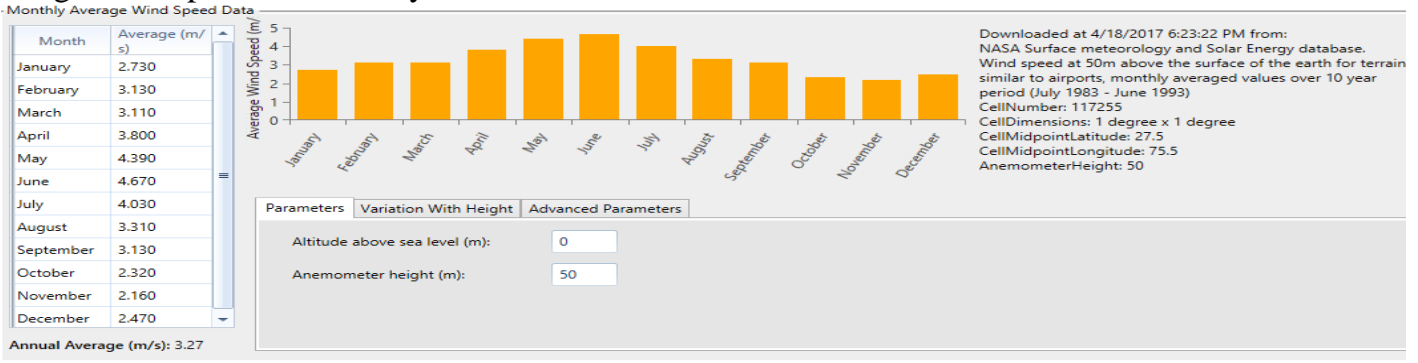

Figure 6:- Graph of Wind Speed

\section{System Converter:-}

Here converter is used which can act both as an inverter and rectifier depending on the direction of flow of power. A converter is used to convert and maintain power flow between DC and AC link. Converter sizes considered are: 1.5, 3 and $7.5 \mathrm{~kW}$. Replacement cost is taken $80 \%$ of the capital cost, efficiency of converter is around $90 \%$ and the lifetime of the converter will end for 15 years. Converter size is considered $0,1.5,3,4.5,6,7.5 \mathrm{~kW}$. The operation cost for such type of converter is $\$ 7200$ and replacement cost is $\$ 3054.77$. Maintenance free converter system is assumed.

\section{Result and Discussion:-}

\section{Optimization Results:-}

Case study a) when hybrid system comprises of Solar PV, Wind turbine, diesel Generator, battery and Converter. From the simulation it is found that $9 \mathrm{~kW}$ PV panel, $12 \mathrm{~kW}$ generator, $12 \mathrm{~V}$ Battery and $5 \mathrm{~kW}$ converter is the optimal 
solution for overall system. In this system initial cost is $19,808 \$$ and operating cost is $7,284 \$$ year whereas cost of electricity is $0.206 \$$. For more accurate result simulation run into three value of solar radiation, wind speed and fuel price, the values are rage of minimum to maximum value. By these values three cases are formed.

Scenario I: In scenario 1 solar radiation and wind speed are at their maximum value where as fuel price at their minimum value. In this case PV, diesel generator and battery are best solution economically shown in table 3 . While $\mathrm{PV}$, Wind turbine, diesel generator and battery system is a good alternative having litter higher cost of energy, listed in second position.

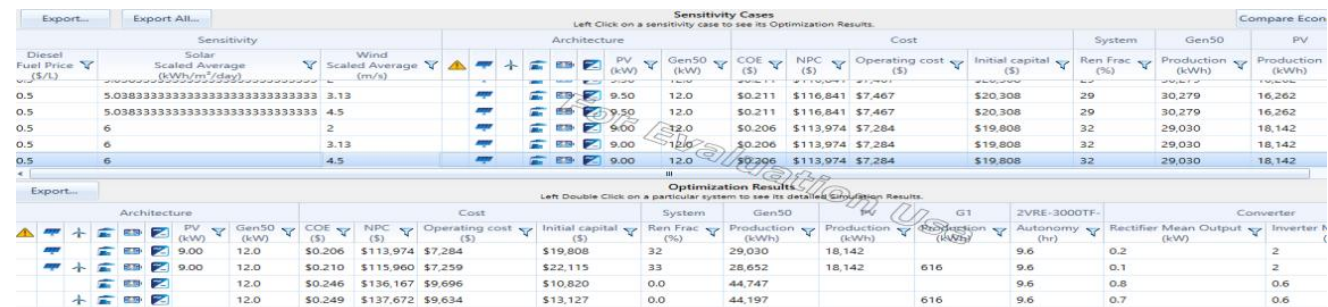

Figure 7:- Optimization Results for Maximum nonconventional Resources and Minimum Fuel Price

Scenario 2:- In scenario 2 solar radiation, wind speed and fuel price are at their actual average value. In this case $\mathrm{PV}$, diesel generator and battery is also economically best solution listed in table 4 . The second listed system is also a good alternative having litter big net present cost. Renewable fraction for both first and second system is same.

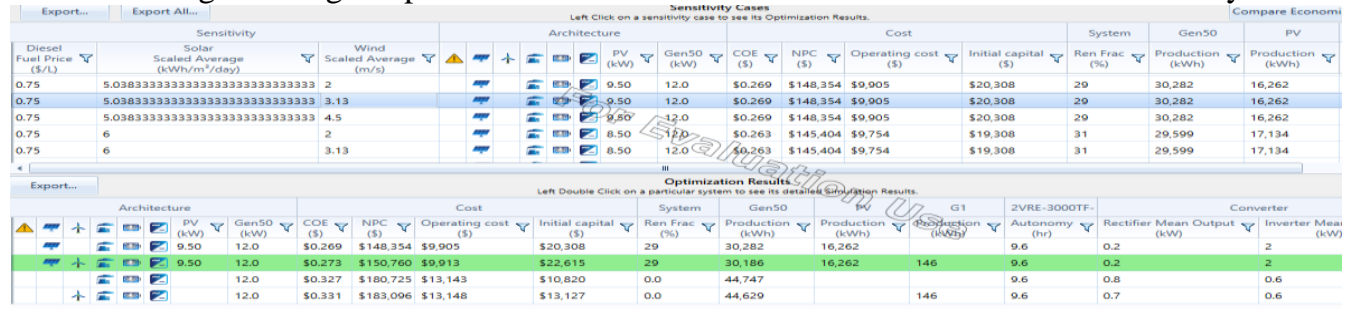

Figure 8:- Optimization Results for Actual Average Values

Scenario 3: In scenario 3 solar radiation, wind speed and diesel price are at their minimum value. In this case PV, Diesel Generator and battery is still economically best solution, listed in first position is the table 2 . The second hybrid system having PV, Wind Turbine, Diesel Generator and battery is still best alternative solution.

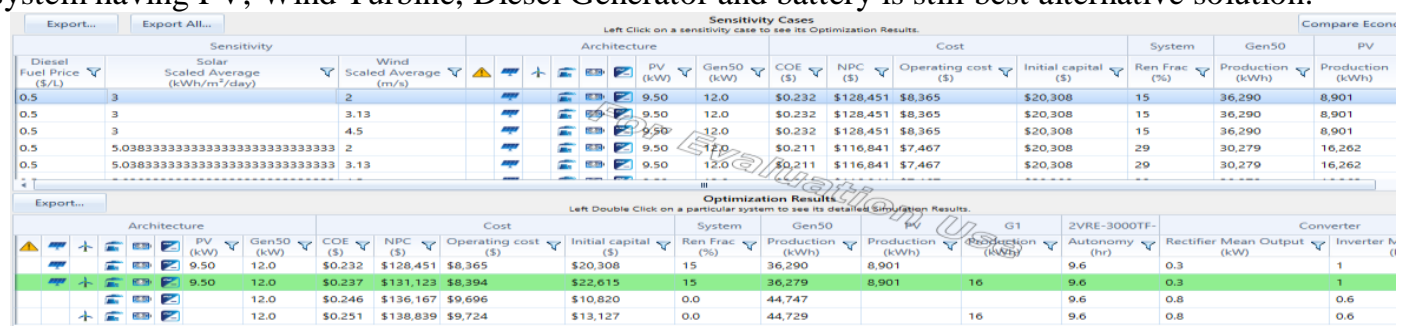

Figure 9:- Optimization Results for Minimum non-conventional Resources and Minimum Fuel Cost

Case Study b) when hybrid system comprises of Solar PV, diesel Generator, battery and Converter.

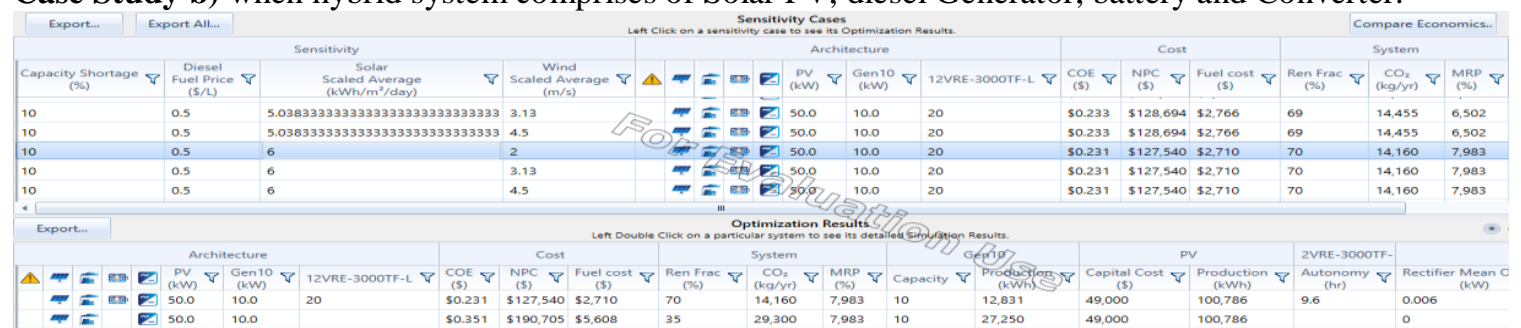

Figure 10:- Optimization Results 


\section{Comparative Analysis of Case study 'a' and Case Study 'b':-}

In this, when comparison is being done among the cost of electricity (COE) in three different arrangements where first is with Solar PV, wind turbine and Diesel generator, Second arrangement is of Solar PV and Wind turbine and third is considered from utility. Then Cost of Electricity is as follows as shown in table 3.

Table 3:- Comparison in COE, Net Present Cost (NPC) and Renewable Fraction (1 Dollar = 64.28 Indian Rs)

\begin{tabular}{|l|c|c|c|}
\hline System Arrangement & $\begin{array}{c}\text { Cost of Electricity } \\
\text { (COE) (\$) }\end{array}$ & $\begin{array}{c}\text { Net Present } \\
\text { Cost(NPC) } \mathbf{( \$ )}\end{array}$ & $\begin{array}{c}\text { Renewable } \\
\text { Fraction }\end{array}$ \\
\hline Solar PV, wind turbine and Diesel generator & 0.206 & 113,974 & 32 \\
\hline Solar PV and Diesel generator & 0.231 & 127,540 & 70 \\
\hline
\end{tabular}

C. Sensitivity Results:-

The graphical sensitivity results provide a different view of results; it shows solar radiation and wind speed varies from minimum to maximum with the different values of diesel prices as shown in figure 6 to 8 respectively. The surface plot for the levelized cost of energy with total net present cost superimposed is presented in Figure 6. The fuel price is fixed at $\$ 0.5 / \mathrm{L}$ the solar radiation is depicted on the $\mathrm{x}$-axis and wind speed on the $\mathrm{y}$-axis. This shows that cost of energy is lower when the solar radiation is higher. From the figure 6 to 8 it is found that at the higher value of fuel cost the cost of energy is higher and with the lower value of fuel cost the cost of energy is lower.

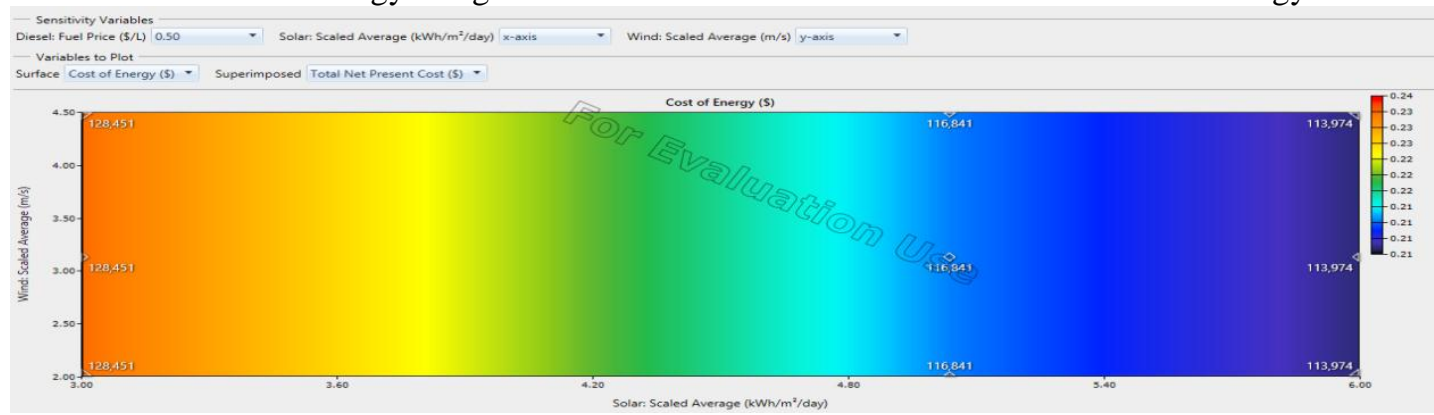

Figure 11:- Surface Plot of Cost of Electricity with Diesel Price of \$ 0.5/L.

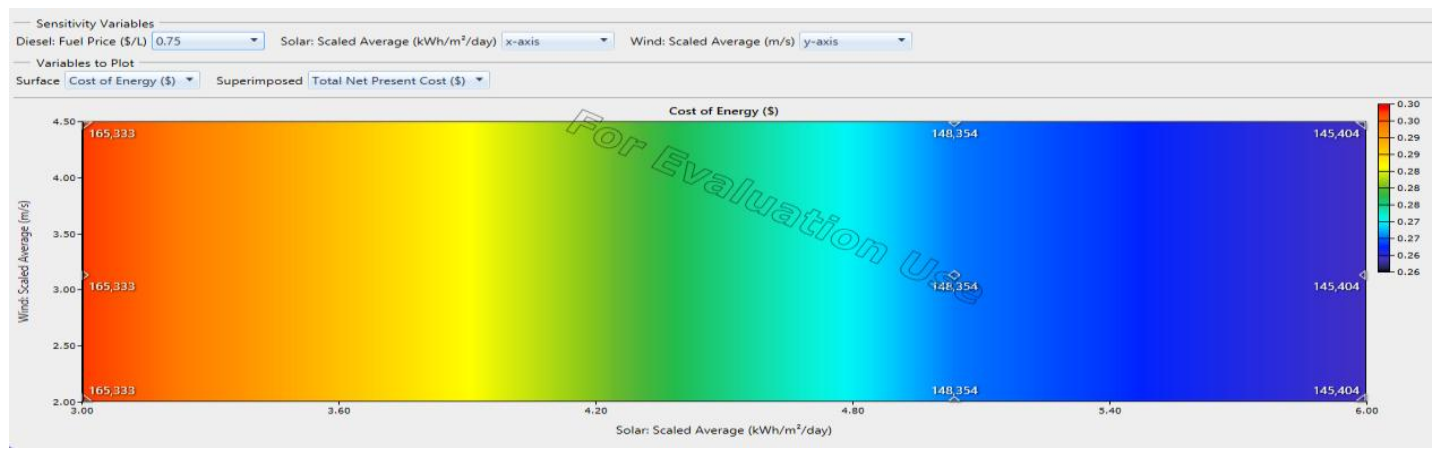

Figure 12:- Surface Plot of Cost of Electricity with Diesel Price of $\$ 0.75 / \mathrm{L}$

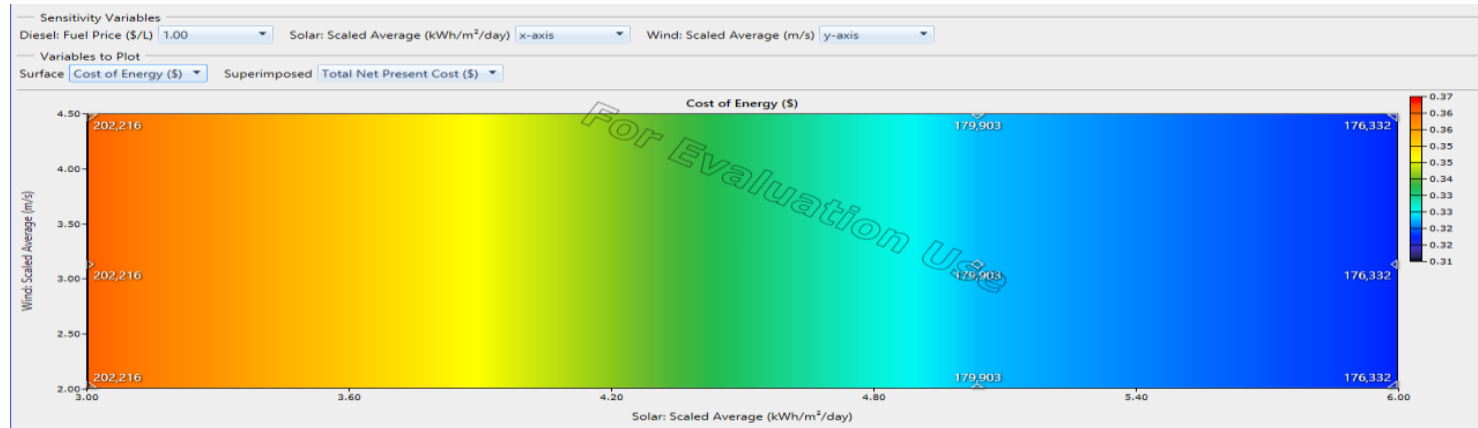

Figure 13:- Surface Plot of Cost of Electricity with Diesel Price of \$1/L. 
In sensitivity results, the line plot for fuel, solar and wind are studied to see the variation by plotting for different variables such as Cost of Energy and Net Present Cost. In the first case, it is obtained for Cost of Energy with respect to diesel, solar and wind resource and in the second case, line plot is obtained for NPC with respect to diesel, solar and wind resource as shown in figures 14, 15, 16 and 17 respectively.

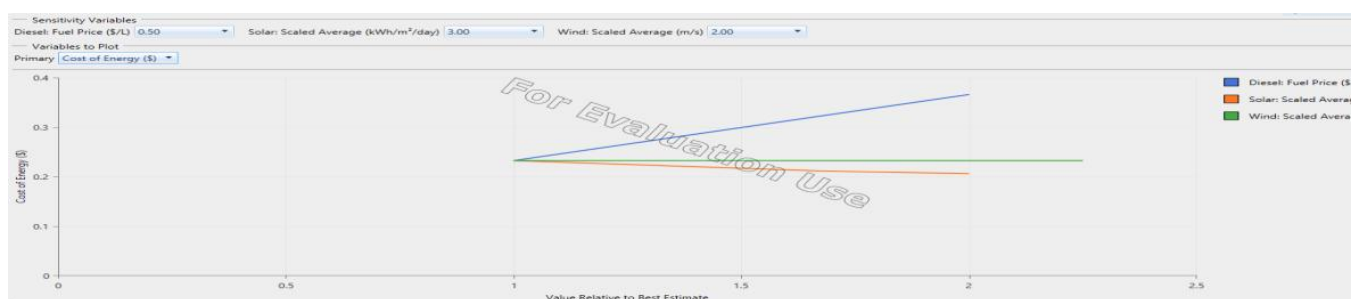

Figure 14:- Line Plot of Cost of Energy with Diesel price $\$ 0.50 / \mathrm{L}$, Solar $(\mathrm{KWh} / \mathrm{m} 2 / \mathrm{day})$ at 3 and wind $(\mathrm{m} / \mathrm{s})$ at 2

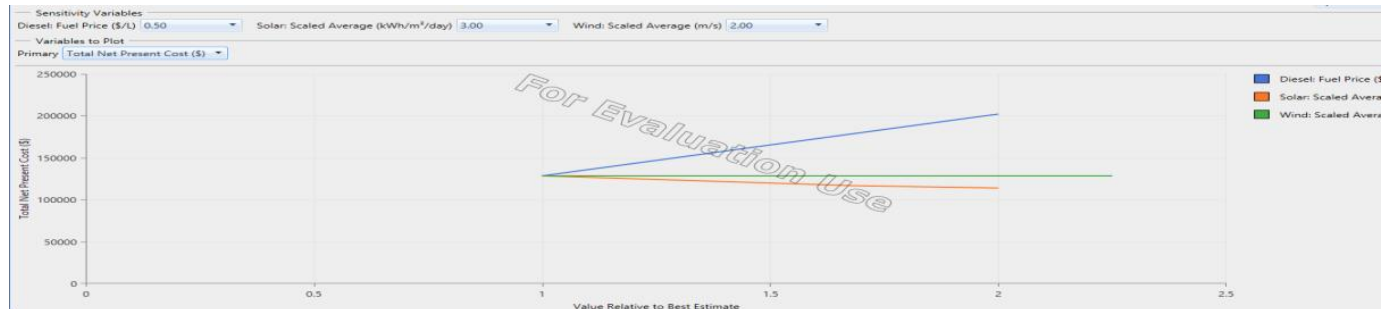

Figure 15:- Line Plot of Cost of Energy with Diesel price $\$ 0.50 / \mathrm{L}$, Solar $(\mathrm{KWh} / \mathrm{m} 2 /$ day) at 3 and wind $(\mathrm{m} / \mathrm{s})$ at 2

In sensitivity results, optimal system time plot for different variables such as total net present cost and fuel cost is also studied. In this case, variable to be studied which is Total Net Present Cost (\$) is superimposed and optimal system is obtained for the same with diesel fuel price on $\mathrm{x}$ axis and solar average on y axis by keeping wind average as constant to $2 \mathrm{~m} / \mathrm{s}$ as shown in figure

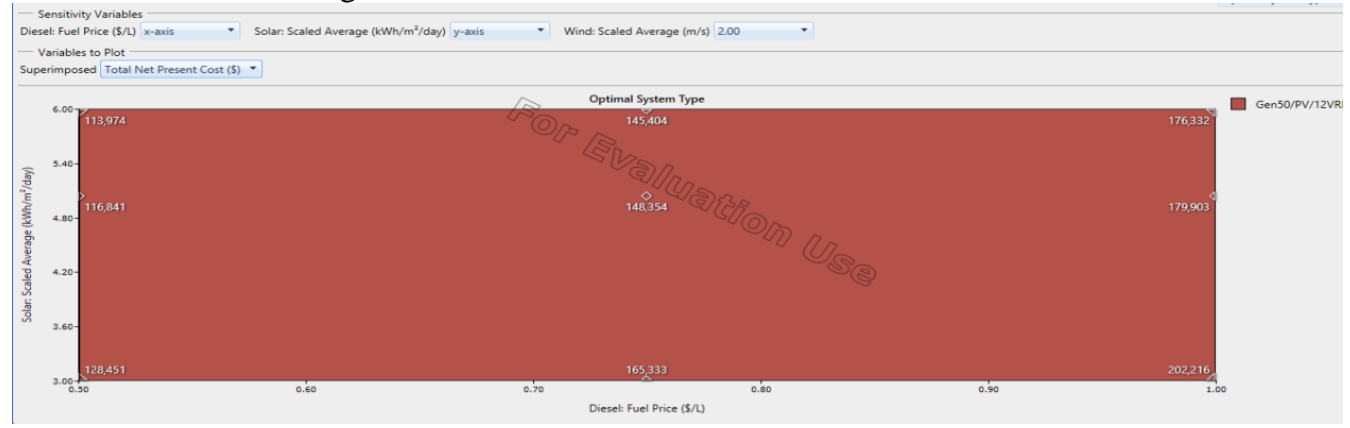

Figure 16:- Optimal System Type Plot of Total Net Present Cost

In this case, variable to be studied which is Fuel Cost (\$) is superimposed and optimal system is obtained for the same with diesel fuel price on $\mathrm{x}$ axis and solar average on $\mathrm{y}$ axis by keeping wind average as constant to $2 \mathrm{~m} / \mathrm{s}$ as shown in figure

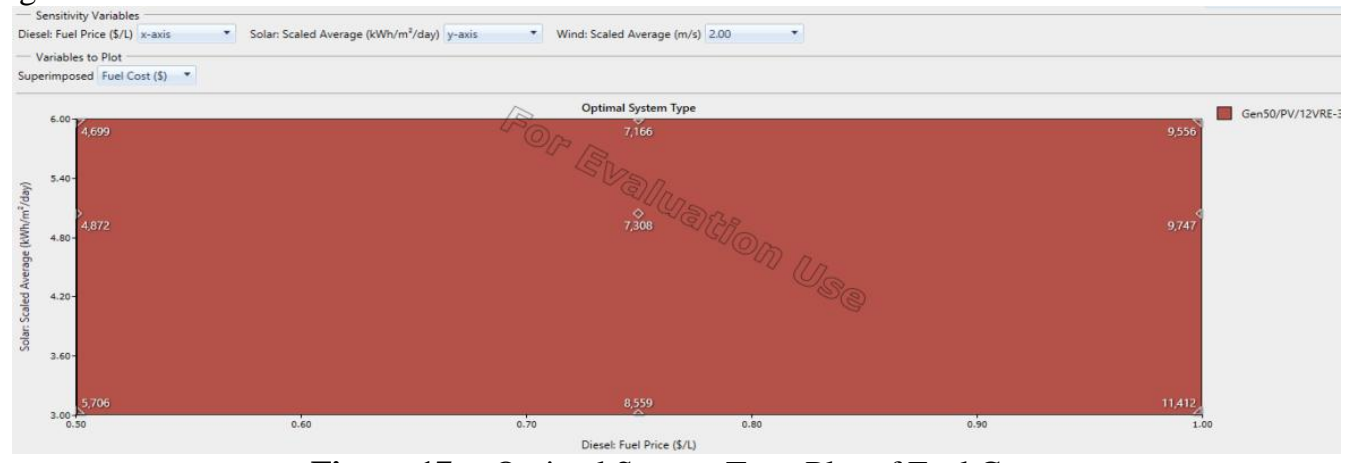

Figure 17:- Optimal System Type Plot of Fuel Cost 


\section{Conclusion:-}

The result from the HOMER shows that in the case where system arrangement consists of PV, Wind Turbine Diesel Generator with battery and inverter. Then in the case of PV, Diesel Generator with battery and inverter is most economical solution for all three cases of Optimization for the load of library of CET, MUST. PV, Wind Turbine, Diesel Generator with battery and inverter system is also a very good alternative solution having little higher cost of electricity and net present cost. Although the cost of electricity from the proposed system is higher than the cost grid electricity but due to the necessity of environmental protection and farseeing the current living standard of rural communities such hybrid system will play a very good role for the country like India having deficit electricity.

\section{References:-}

1. Vikas Khare, Savita Nema and Prashant Baredar, "Status of solar wind renewable energy in India", Renewable and Sustainable Energy Reviews, vol. 27, pp. 1-10, 2013.

2. Andrea Vallati, Stefano Grignaffini and Marco Romagna, "A New Method to Energy Saving in a Micro Grid", Sustainability, vol. 7, pp. 1390413919, 2015.

3. Eduardo F. Silveira et al., "Hybrid energy scenarios for Fernando de Noronha archipelago", Energy Procedia, vol. 75 , pp. 2833-3838, 2015.

4. Deepak Kumar Lal, et al., "Optimization of PV/wind/Micro-Hydro/Diesel Hybrid Power System in HOMER", International Journal on Electrical Engineering and Informatics, vol. 3, pp. 307-325, 2011.

5. Munuswamy, S., Nakamura, K., Katta, A., "Comparing the cost of electricity sourced from a fuel cell-based renewable energy system and the national grid to electrify a rural health centre in India: A case study", Renewable Energy, vol. 36, pp. 2978-2983, 2011.

6. K.R. Ajao et al., "Using HOMER Power Optimization Software for Cost Benefit Analysis of Hybrid-Solar Power Generation Relative to Utility Cost in Nigeria", International Journal of Research and Reviews in Applied Sciences, vol. 7,pp. 96-102, Apr. 2011.

7. Abbas Babaei et al., "Optimizing and Economical Assessment of the Utilization of Photovoltaic Systems in Residential Buildings: The Case of Sari Station, Northern of Iran", Australian Journal of Basic and Applied Sciences, vol. 6, pp 133-138, 2012.

8. HOMER, The Micro-Power Optimization Model, ver.2.68 Beta, NREL, 2009.

9. Urjakart.com, Buy solar panel, solar power plant online in India [Online] Available http://www.urjakart.com/solar.

10. Bergey wind power [Online] Available http://bergey.com/

11. Green Wind Energy, Roadmap to Small Wind Turbines in India [Online] Available http://greenwindenergy.net/smallwindturbinetech nology.html.

12. Mahindra Powerol, Diesel generator/DG set manufacturer in India [Online] Available http://www.mahindrapowerol.com/.

13. Price list, List of portable generator [Online] Available http://www.pricelist.co.in/index.php/office/gener ators/portable-generators. 